\title{
Breve historia de la palabra
}

Fernán Odio Fonseca

Facultad de Comunicación

Universidad de Navarra

$\mathbf{L}$ a teoría de la Comunicación sigue vigente con una incógnita dentro de su propio conocimiento. Es compleja la cantidad de teorías que hasta el momento proliferan, abordando el cómo $\mathrm{y}$ el qué del fenómeno comunicativo. Seguimos teniendo ese dulce sentido científico que nos da la certeza del uso de una herramienta humana. Pero hay más que sólo hechos físicos: la comunicación humana $(\log o s)$ en sí misma es una acción que aporta una cualidad en el ser del que la utiliza. Esta facultad, más que instrumento, también es integral a nuestra naturaleza; es decir, nos perfecciona, gracias a otros seres. Esto conlleva a la necesidad de la socialización con semejantes, y de manera posterior, a la política. La palabra $(\log o s)$, y no el ruido, es la capacidad de dar un orden lógico a la existencia, de entenderla y descifrarla. Sólo la brújula de la libertad humana podrá delimitar la certeza de la falsedad.

Dice el filósofo Alfredo Cruz Prados que la polis griega fue una forma de perfeccionar nuestra naturaleza como seres sociales: esto quiere decir, seres con necesidades cognitivas físicas, espirituales y políticas. Lo social, por obligación, requiere de la palabra humana. La historia de la humanidad está llena de diferentes concepciones del mundo: ¿Qué es el hombre?, ¿Qué es el alma?, ¿Qué es la moral? No hay duda de que nuestra comunicación no se limite a la espontaneidad instintiva, ya que no seríamos capaces de intentar responder a estas preguntas. Bajo esta premisa: ¿Cuál es la mejor forma de comunicación? La que nos incline hacia la perfección como seres sociales por naturaleza. Esto no quiere decir que todo lo que se diga en la sociedad perfeccione. La perfección está relacionada con el enriquecimiento colectivo. La palabra no es ruido. No es azar. Es razón y lógica que esclarece. La palabra es perfecta por naturaleza; lo que es imperfecto es el uso que se le da a ella.

Juan José García-Noblejas, profesional en el ámbito de comunicación pública y audiovisual, afirma que es de suicidas suponer que los asuntos más importantes en la actual revolución digital son asuntos de índole tecnológica o económica. Esto subraya el paradigma comunicativo actual, donde, en algunos casos, la palabra parece estar exenta de propósitos integradores y solidarios. Esto no quiere decir que el comunicador es equivalente a una especie de 
puritano mediático. Pero no sería dañino el hecho de diseccionar los conceptos actuales de "palabra" y "persuasión" tecnológica. No es exagerado suponer una posible dictadura mediática, un relativismo que acampana en cada una de las concepciones de lo espiritual, físico y político. La "hipertrofia informática" podría sobrepasar a la razón de la palabra $(\log o s)$, lo cual plantea un serio problema de cara a la mentalidad del futuro. ¿Cómo podemos volver a la razón natural de la palabra? Esto es cometido de todos aquellos que la dominen. 